\title{
The Quantification of Atmospheric Emissions from Complex Configuration Sources using Reverse Dispersion Modelling
}

\author{
Oladapo Akinshipe ${ }^{* 1,2}$ and Gerrit Kornelius ${ }^{1}$ \\ ${ }^{1}$ Environmental Engineering Group, Chemical Engineering, University of Pretoria, South Africa, oladapoak@gmail.com \\ ${ }_{2}^{2}$ Airshed Planning Professionals (Pty) Ltd. PO Box 5260, Midrand, South Africa.
}

\begin{abstract}
Reverse dispersion modelling was employed to quantify sulfur dioxide $\left(\mathrm{SO}_{2}\right)$ and nitrogen dioxide $\left(\mathrm{NO}_{2}\right)$ emissions from brick firing clamp kilns and spontaneous combustion from a coal discard dump. Reverse dispersion modelling technique integrates ambient monitoring and dispersion simulation to calculate actual emission rates from an assumed rate of $1 \mathrm{gram}$ per second $(\mathrm{g} / \mathrm{s})$. Emission rate and emission factor was successfully quantified for $\mathrm{SO}_{2}$, but not for $\mathrm{NO}_{2}$, due to the influence of external sources and the complexity regarding the varying proportion of nitrogen oxides released from the kiln. Quantified emission factor for clamp kiln firing ranged from 1.91-3.24 grams of $\mathrm{SO}_{2}$ per brick fired and 0.67-1.14 grams of $\mathrm{SO}_{2}$ per kilogram of bricks fired. The variation in $\mathrm{SO}_{2}$ emission factors was linked to high variability in energy input. The source configuration input to the dispersion model, assumed to represent the kiln, was changed from a volume source to a more effective "bi-point" source situated at the top of the kiln, with buoyancy calculated from the carbon combustion rate. $\mathrm{SO}_{2}$ emission rate for spontaneous combustion from the discard dump was quantified as $0.35 \mathrm{~g} / \mathrm{s}$. 274 tons of discard material was estimated to burn annually, assuming that the emission rate is consistent over a year. Consequently, the reverse dispersion modelling and the elevated "bipoint" source technique may be considered a novel approach for quantifying emissions from combustion of materials or mixture of materials where knowledge of source parameters is limited.
\end{abstract}

KEYWORDS: back-calibration; bi-point source; clamp kiln; dispersion modelling; emission factor; reverse dispersion modelling; spontaneous combustion;

\section{Introduction}

Sources of atmospheric emissions, such as clamp kilns for firing bricks, combustion of coal discard, forest fires or burning bush and municipal waste dumps etc., may be regarded as complex sources due to their irregular configurations. These complex sources emit atmospheric pollutants that do not conform to conventional dispersion modelling source configuration (including point, area, volume, pit, flare and jet sources). The quantification of atmospheric emissions for dispersion modelling and air quality impact assessment purposes, as well as the mitigation or management of emissions from these sources has proven difficult or impossible due to inadequate emission data and techniques for estimating emission metrics; large scale and diffuse nature of the emissions, rendering monitoring difficult; and inadequate techniques for channelling emissions into a point or volume stream (Cardenas et al. 2009; Carras et al. 2009; Irm 2011; Umlauf et al. 2011; DEA 2012)

Since emission metrics and parameters are not readily available, this renders emission quantification, impact assessment, mitigation and management measures for these sources difficult or impossible to achieve. In this study, a reverse dispersion modelling technique was applied to two complex source configurations (clamp kilns for firing clay bricks and spontaneous combustion from a coal discard dump at a South African coal mine) in order to quantify the rate of emissions as well as other useful emission metrics.

\subsection{Clamp kiln for firing bricks}

Clamps are traditional kilns, invented by Egyptians around 4000 BC. They are the most commonly used kiln type in developing countries, including India and South Africa (Baum 2010; Rajasthan State Pollution Control Board 2011; Guttikunda et al. 2012; Maithel et al. 2012; Smith 2013; CBA 2015). The bricks are packed in a pyramid-shaped formation with a layer of combustible material such as coke, cinder or coal at the bottom of the kiln (Figure 1). The typical fuel used in South African clamp kiln is coal, comprising both body fuel (mixed into the clay during processing) and external fuel (packed in the base layer). When the base layer of coal is ignited, it sets the bricks on fire layer by layer until the whole kiln is ablaze. The kiln temperature rises gradually, igniting the fuel in the clay at about $800^{\circ} \mathrm{C}$ and peaking at a range of $1200-1400{ }^{\circ} \mathrm{C}$ at the centre of the kiln (CBA 2002; Rajasthan State Pollution Control Board 2011; CBA 2015). While previously published works applying reverse dispersion modelling to atmospheric emissions quantification at clamp kiln sites are not available, recent studies have quantified emission from brick kiln sites including Le and Oanh (2010), Irm (2011), Weyant et al. (2014) and Maithel et al. (2012). 


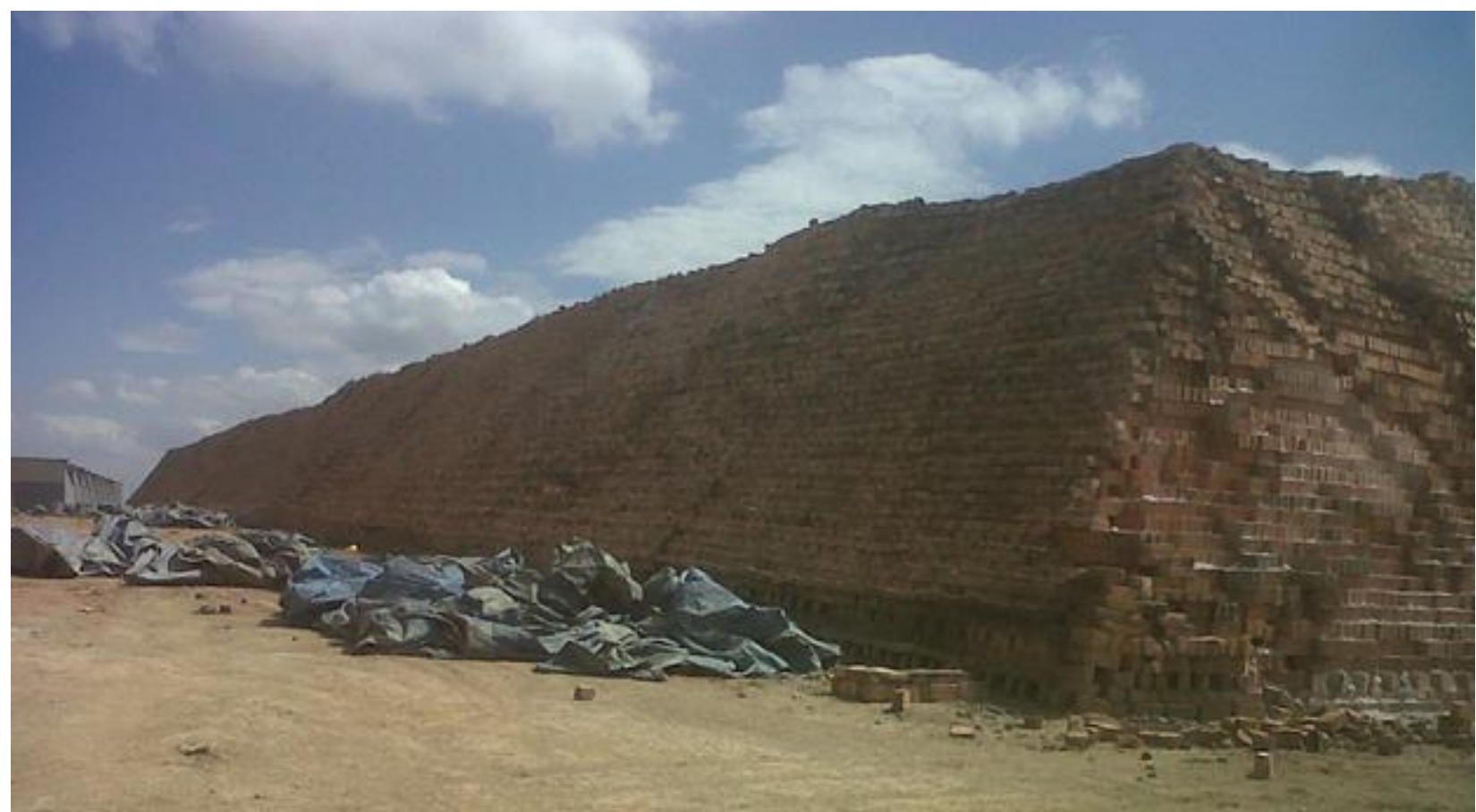

Figure 1: A clamp kiln at Berts' Bricks, South Africa, firing over seven million bricks in 21 days (Note: emission capture and containment or extraction is not feasible)

\subsection{Spontaneous combustion at coal discard dump}

Spontaneous combustion occurs from low-temperature oxidation of carbon-containing materials, including coal, coal discard or waste materials, manure, hay stack etc. (Carras et al. 2009, Zhao et al. 2008; Pone et al. 2007). For combustion to occur, a substance having a low ignition temperature must be exposed to the atmosphere for extended periods, leading to chemical oxidation (exposure to moisture and oxygen) or bacterial oxidation (Adamski 2003; Lu et al. 2004; Pone et al. 2007). Either way, heat is produced and trapped inside the material, leading to temperature rise beyond its ignition point. The presence of adequate oxygen (oxidizer) and fuel enables the maintenance of the combustion reaction, which has been identified as a global environmental concern (Bell et al. 2001; Heffern 2004; Nolter 2004; Stracher 2004; Stracher and Taylor 2004; Whitehouse and Mulyana 2004; Sheail 2005; Chatterjee 2006). Studies such as Carras et al. (2009), Zhao et al. (2008); Pone et al. (2007) and Lu et al. (2004) etc., have attempted to quantify or assess emissions of various pollutants from coal discard sites.

\section{Methodology}

Reverse dispersion modelling is a technique that integrates ambient monitoring with dispersion modelling in order to "standardize" or calibrate actual emission rate from an assumed unit rate - in this case 1 gram per second ( $\mathrm{g} / \mathrm{s}$ ) (Akinshipe 2013). In other words, while modelling is conducted with an assumed emission rate, monitoring is conducted simultaneously over the same period. Actual emission rate and factors are then calculated backwards from the ratio of the measured to the simulated results. This technique is novel in its approach, affording the benefits of circumventing the need for designing and constructing a structure that is required to capture and channel diffuse and complex source emissions into a stream where monitoring can be conducted. It also circumvents the need for comprehensive monitoring and data analysis in order to collect adequate data to quantify the required emission metrics.

Ambient monitoring of emissions from clamp kilns and from a discard dump undergoing spontaneous combustion was undertaken using the Radiello ${ }^{\circledR}$ diffusive sampler, an axial sampler that uses unaided molecular diffusion of gaseous substance such as hydrogen fluoride (HF); ozone $\left(\mathrm{O}_{3}\right)$; hydrogen sulfide $\left(\mathrm{H}_{2} \mathrm{~S}\right) ; \mathrm{SO}_{2}$ and $\mathrm{NO}_{2}$, through a diffusive surface to be adsorbed on an internal surface (Sigma-Aldrich 2016). Thermal or solvent desorption is used to desorb the "analytes" in the laboratory after the sampling period.

Gaussian dispersion modelling suites, including the Atmospheric Dispersion Modelling System (ADMS) and the AMS/EPA Regulatory Model (AERMOD), are valuable and well established tools in the simulation of primary as well as secondary pollutants in carrier media (Prahm and Christensen 1977; Salcedo 1991; Jennings and Kuhlman 1997; Voit and Voit 2000; Clappier et al. 2015). Consequently, ADMS and AERMOD were used to simulate pollutant concentration at the exact sampling locations which the passive samplers were located. Modelling software was selected based on the availability of adequate input and 
meteorological data (Clappier et al. 2015). An emission rate of $1 \mathrm{~g} / \mathrm{s}$ was assumed for each simulation. The simulated and measured concentrations were then compared and the ratio of the measured to the simulated results was utilized in determining the emission rate from each source of emission.

The pollutants of interests in this study include sulfur dioxide $\left(\mathrm{SO}_{2}\right)$, nitrogen dioxide $\left(\mathrm{NO}_{2}\right)$ and particulate matter passing into a sampler whose inlet has a median cut-off of 10 micrometres $\left(\mathrm{PM}_{10}\right)$. These pollutants have been identified both locally and internationally as pollutants of interests in air quality studies and are the most potentially harmful to human and animal health, as well as injurious to vegetation, agriculture and land cover (World Bank 1997; DEA 2010; Ahmad et al. 2011; Assadi et al. 2011; DEA 2012; DEA 2013; Skinder et al. 2014).

\subsection{Clamp Kiln Methodology}

\subsubsection{Ambient monitoring}

$\mathrm{NO}_{2}$ and $\mathrm{SO}_{2}$ passive samplers were installed downwind (using historical local meteorological data to determine the downwind quadrant of the source) of the kiln at three South African clamp kiln sites, representing small scale production (1 million bricks per month - Site A); medium scale production (2.5 million bricks per month - Site B); and large scale production (10 million bricks per month - Site C) respectively. $\mathrm{PM}_{10}$ monitoring could not be conducted in this study due to unavailability of adequate monitoring equipment for measuring ambient emissions from a complex source configuration such as a clamp kiln. Also, fugitive $\mathrm{PM}_{10}$ emissions are released by other activities on site, making it difficult to allocate emissions to a particular source.

Site specific meteorological data was obtained during the passive sampling period using the Wilh. Lambrecht KG Gottingen ${ }^{\circledR}$ cup anemometer (Model Number: 470279). The wind anemometer was set up about $500 \mathrm{~m}$ upwind of the clamp kiln on the three sites. It was mounted on a $10 \mathrm{~m}$ stand and set to due north using a magnetic compass, allowing for local declination. The wind rose from the anemometer and location of samplers around the kiln at Site $\mathrm{C}$ is shown in Figure 2 as an example.

Sampling was performed at about $60 \mathrm{~m}$ to $120 \mathrm{~m}$ downwind of the clamp kiln area and installed at heights ranging from $1 \mathrm{~m}$ to $4 \mathrm{~m}$ above ground level, depending on the topography of each site. An initial dispersion simulation was conducted using Screen View 3.5.0 in order to determine the uptimum sampling position $(60 \mathrm{~m}$ to $120 \mathrm{~m})$ for the passive samplers. All but one of the samplers were positioned downwind of the clamp kiln where they were likely to be exposed to a high concentration of pollutants emitted from the kiln. At least one sampler per site was located upwind of the kiln to monitor the background concentration for the site, with little or no interference from kiln emissions. Samplers were retrieved immediately after kiln firing was completed and sent for $\mathrm{SO}_{2}$ and $\mathrm{NO}_{2}$ processing using the Radiello method $\mathrm{F} 1$ (Sigma-Aldrich 2016). Ambient monitoring was performed for the duration which the bricks were fired at the three sites (14 - 21 days). 




Figure 2: Wind rose and location of samplers (P2 - P7) downwind of kiln at Site 3. (Note: P1 is located upwind to measure background concentration)

\subsubsection{Modelling Input and "Bi-Point" Source Configuration}

Clamp kiln dispersion simulation was undertaken using ADMS. ADMS requires users to input information stipulating the source release conditions, meteorological conditions and details of the output desired (CERC 2010). Source and input data were prepared and employed as shown in Table 1. It is assumed that all the energy in both body and external coal is used up during kiln firing.

The dimension of clamp kilns makes the volume source the best selection for the modelling input. However, CERC (2010) describes the ADMS volume source as an area source with vertical extent but no plume rise. This implies that the volume source modelling does not account for plume rise due to buoyancy from the relatively hot gas emitted during firing. The model regards the source as similar to a fugitive emission around a building. Recent studies (Burger and Breitenbach 2008; Potgieter and Jansen 2010) using volume source modelling for clamp kiln has returned a very low emission rate when compared with results of mass balance calculations.

Therefore, in order to account for plume rise due to buoyancy, the clamp kiln source was modelled as two point sources ("bi-point"), as shown in Figure 3. ADMS is capable of simulating the diameter of a point source up to a $100 \mathrm{~m}$. Modelling the clamp kiln as two (or more) large diameter point sources circumvents this limitation for clamp kilns that may have a diameter larger than $100 \mathrm{~m}$, and allows the use of buoyancy in the simulation.

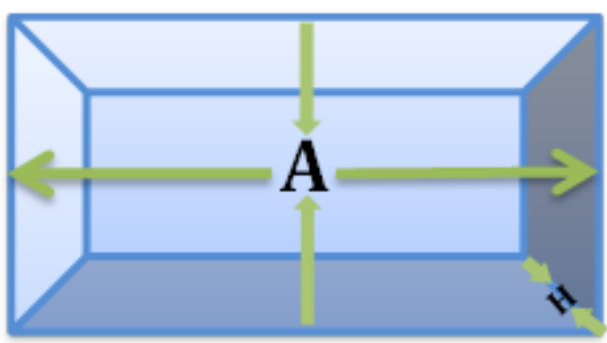

Clamp Kiln
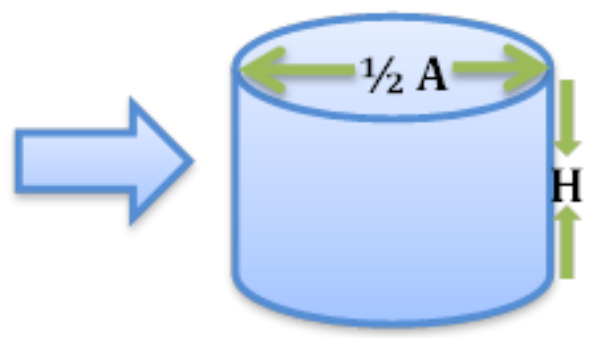

Point 1

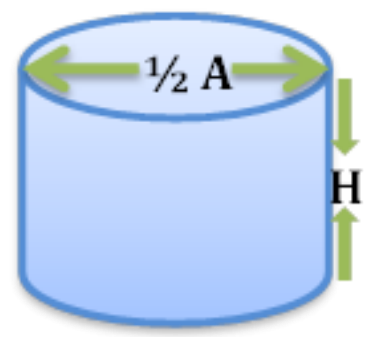

Point 2

Where: $\mathrm{A}=$ Area, $\mathrm{H}=$ Height. Diameter, $\mathrm{D}=\sqrt{ }\left(\frac{4 \mathrm{~A}}{\pi}\right)$

Figure 3: Clamp kiln configuration as two large-diameter point sources 
It is assumed in this design that the kiln emits flue gas only from the top surface. Emission from the sides of the kiln was accounted for, by configuring the surface of the "bi-point" source to be equivalent to the dimension of the base of the kiln, but the "bi-point" source is assumed to be situated at the top level of the actual kiln.

This approach may be adapted to kilns of different shapes (e.g. a long rectangle) by utilizing more than two point sources in such a way that the point sources effectively cover the bottom footprint of the kiln.

\subsection{Coal Discard Methodology}

Similarly, $\mathrm{SO}_{2}$ and $\mathrm{NO}_{2}$ passive samplers were installed downwind of the emission plume from a coal discard dump (Site D) at a South African coal mine (Figure 4). Site specific meteorological data collection, as well as ambient monitoring was undertaken in similar fashion to the clamp kiln monitoring methodology described in Section 2.1.1. Dispersion simulation for the coal discard dump was done using AERMOD (source and input data are shown in Table 1). A "polygon area" source configuration was utilized for the discard dump, with emission released at the top of the discard. Emissions from the discard are not deemed to be buoyant, since they are released at near-ambient temperatures.

The passive samplers were exposed for a period of 14 days on site, after which they were collected and returned to the laboratory for analysis. Dispersion simulation was also conducted for the exact same period, utilizing meteorological data for the exact dates for which the passives were exposed.

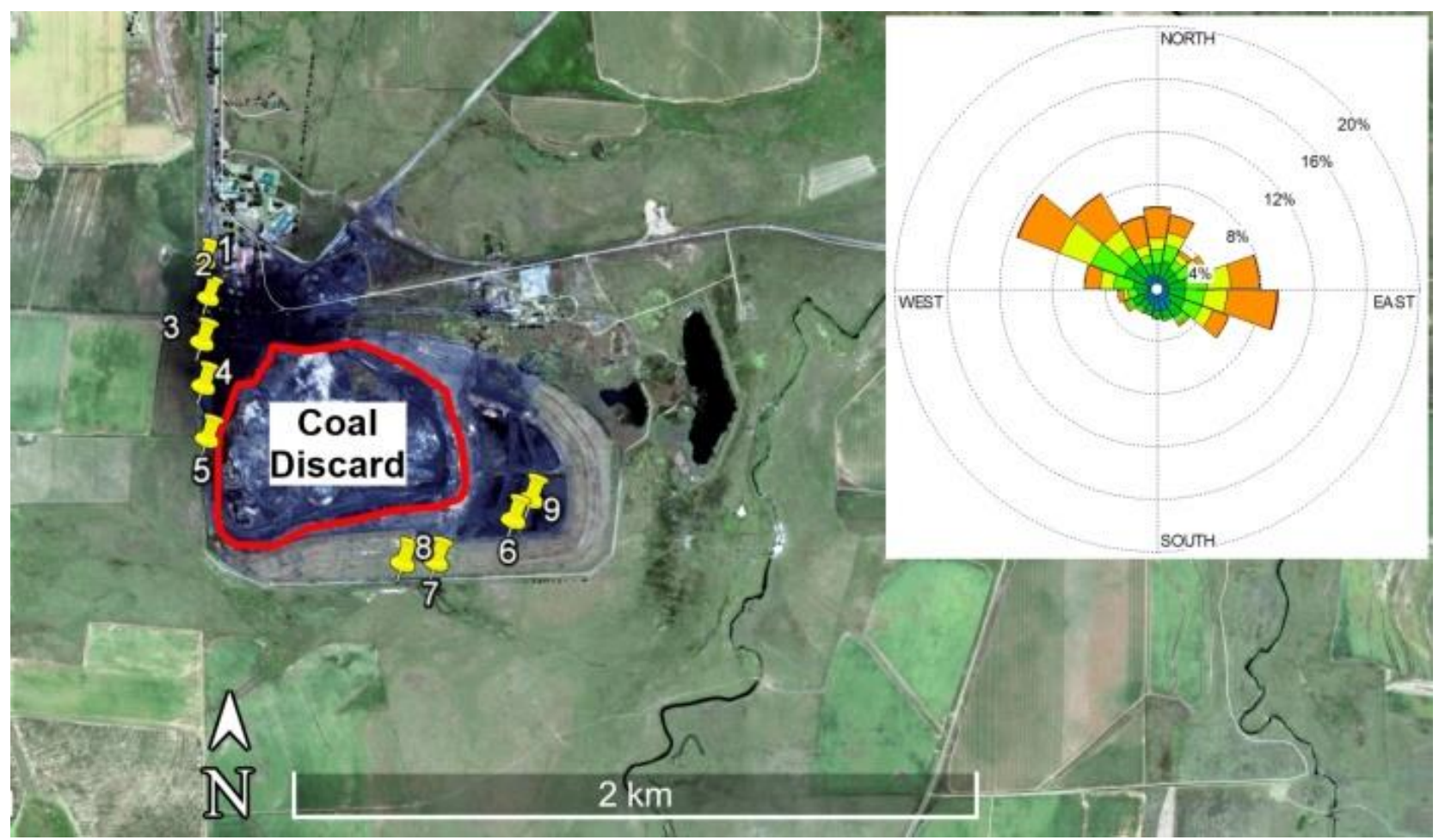

Figure 4: Wind rose and location of samplers (P1 - P9) downwind of coal discard. (Note: Passive samplers are located downwind of dominant wind direction) 
Table 1: Modelling input data for clamp kiln and discard dump site

\begin{tabular}{|c|c|c|c|c|}
\hline Parameter & $\begin{array}{c}\text { Site A } \\
\text { (clamp kiln) }\end{array}$ & $\begin{array}{c}\text { Site B } \\
\text { (clamp kiln) }\end{array}$ & $\begin{array}{c}\text { Site C } \\
\text { (clamp kiln) }\end{array}$ & $\begin{array}{c}\text { Site D } \\
\text { (discard dump) }\end{array}$ \\
\hline \multicolumn{5}{|l|}{ Source and Input } \\
\hline Model Used & ADMS & ADMS & ADMS & AERMOD \\
\hline Source type & Point $^{\mathrm{a}}$ & Point $^{a}$ & Point $^{a}$ & Polygon Area \\
\hline Number of source ${ }^{\mathrm{b}}$ & 2 & 2 & 2 & 1 \\
\hline Emission rate $^{c}(\mathrm{~g} / \mathrm{s})$ & 1 & 1 & 1 & 1 \\
\hline Efflux format & $\mathrm{Fm}, \mathrm{Fb}$ & $\mathrm{Fm}, \mathrm{Fb}$ & $\mathrm{Fm}, \mathrm{Fb}$ & - \\
\hline Release height (m) & 4.4 & 4.2 & 4.4 & 15 \\
\hline Diameter of each source & 30.31 & 54.44 & 34.42 & - \\
\hline $\mathrm{Fm}\left(\mathrm{m}^{4} / \mathrm{s}^{2}\right)^{\mathrm{d}}$ & 1 & 1 & 1 & - \\
\hline $\mathrm{Fb}(\mathrm{MW})^{\mathrm{e}}$ & 3.77 & 13.72 & 3.06 & - \\
\hline Initial vertical dimension (m) & - & - & - & 3.49 \\
\hline Surface area $\left(\mathrm{m}^{2}\right)$ & - & - & - & 339835.8 \\
\hline Energy input (MJ/kg) & \multirow[t]{2}{*}{4.49} & 2.73 & 1.41 & - \\
\hline \multicolumn{4}{|l|}{ Meteorology } & \\
\hline Surface roughness $(\mathrm{m})$ & 0.5 & 0.8 & 0.5 & - \\
\hline $\begin{array}{ll}- & { }^{\mathrm{a}} \text { Point source modellir } \\
\text { - } & { }^{\mathrm{b}} \text { Refer to section } 2.1 .2 \\
\text { - } & { }^{\mathrm{c}} \text { Since emission rate } \mathrm{f} \\
& \text { actual emission rate c } \\
\text { - } & { }^{\mathrm{d}, \mathrm{e}} \mathrm{Fm}\left(\mathrm{m}^{4} / \mathrm{s}^{2}\right) \text { and } \mathrm{Fb} \\
& \text { parameters as alterna } \\
\text { - } & \text { Fm was taken as a sin }\end{array}$ & $\begin{array}{l}\text { r than area or vo } \\
\text { kiln is not known } \\
\text { ack-calculated" } \\
\text { the momentum } f \\
\text { the velocity, volu } \\
\text { since momentun } \\
\qquad \begin{array}{r}\text { Where: } \quad F b= \\
q=Q \\
C V= \\
t=\text { tim }\end{array}\end{array}$ & $\begin{array}{l}\text { urce). } \\
\text { rate of } 1 \mathrm{~g} / \mathrm{s} \text { is a } \\
\text { easured results. } \\
\text { nission and heat } \\
\text { rate or mass flux } \\
\text { minimum. Fb wa } \\
\frac{x \mathrm{cv}}{t} \\
\text { MW } \\
\text { f coal used, kg } \\
\text { energy of coal us } \\
\text { hds }\end{array}$ & $\begin{array}{l}\text { in order to gene } \\
\text { pectively. ADMS } \\
\text { mperature and o } \\
\text { lated from the en }\end{array}$ & $\begin{array}{l}\text { centrations from which } \\
\text { the input of these two } \\
\text { CERC 2010). } \\
\text { ut as follows: }\end{array}$ \\
\hline
\end{tabular}

\section{Results and Discussions}

\subsection{Clamp Kiln Results}

The isopleth plot showing the maximum hourly downwind $\mathrm{SO}_{2}$ concentration for an emission rate of $1 \mathrm{~g} / \mathrm{s}$ at site $C$ (with position of the ambient measuring points indicated) is illustrated in Figure 5 . Sampling point 1 is located upwind (north of the contours) and is consequently taken as background concentration. Measured and modelled $\mathrm{SO}_{2}$ results are presented in Table 2 for all three clamp kiln sites. 


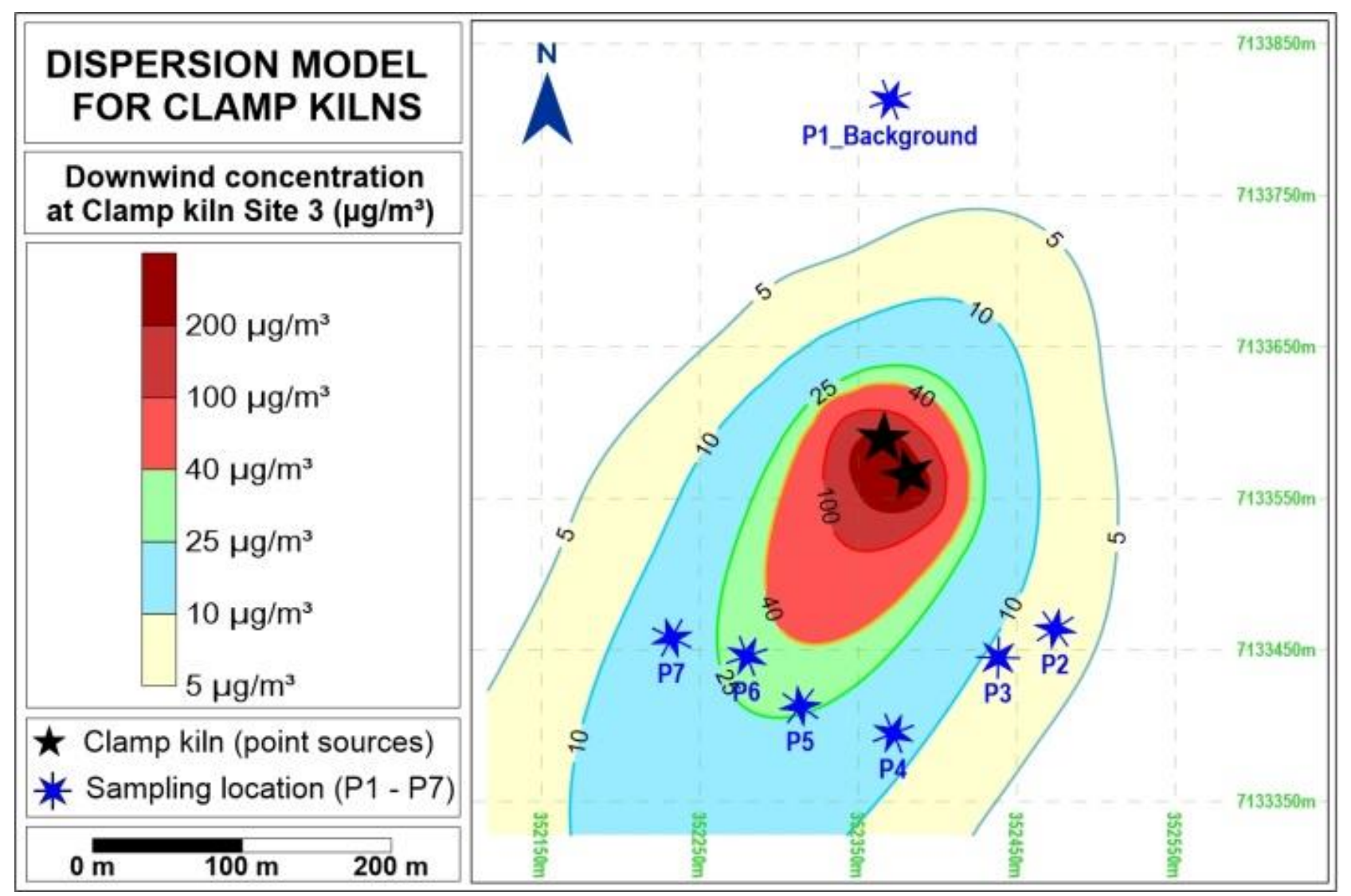

Figure 5: Modelled maximum hourly downwind concentration for $\mathrm{SO}_{2}$ in $\mu \mathrm{g} / \mathrm{m}^{3}$

Multiplying the ratio of measured to modelled concentration values for each measuring point by the frequency of the wind in the sector (illustrated in Figure 6 below) that sends the plume over that point allows the weighting of each measuring result by its exposure to the kiln emissions, and hence provides an average ratio. As ambient concentrations are linearly proportional to emission rates, this allows the calculation of the average emission rate of pollutant over the firing period. This methodology is described step-by-step in Table 3.

Statistical analyses of data were performed using GNU PSPP version 0.9. Spearman's rank correlation coefficient analysis was performed to indicate the direction and strength of the linear relationship between the measured and simulated data from the three clamp kiln sites. Analyses were performed with a $95 \%$ confidence interval. A very strong positive correlation was observed between measured and simulated data for site $A(r=0.89, n=6, p<0.19)$ and site $B(r=0.87, n=10, p<0.001)$; while a strong positive correlation was observed for site $\mathrm{C}(\mathrm{r}=0.79, \mathrm{n}=7, \mathrm{p}<0.036)$. This suggests that $\mathrm{SO}_{2}$ emission contribution from external sources apart from the kilns is limited, offering a high degree of confidence in the measured data. 


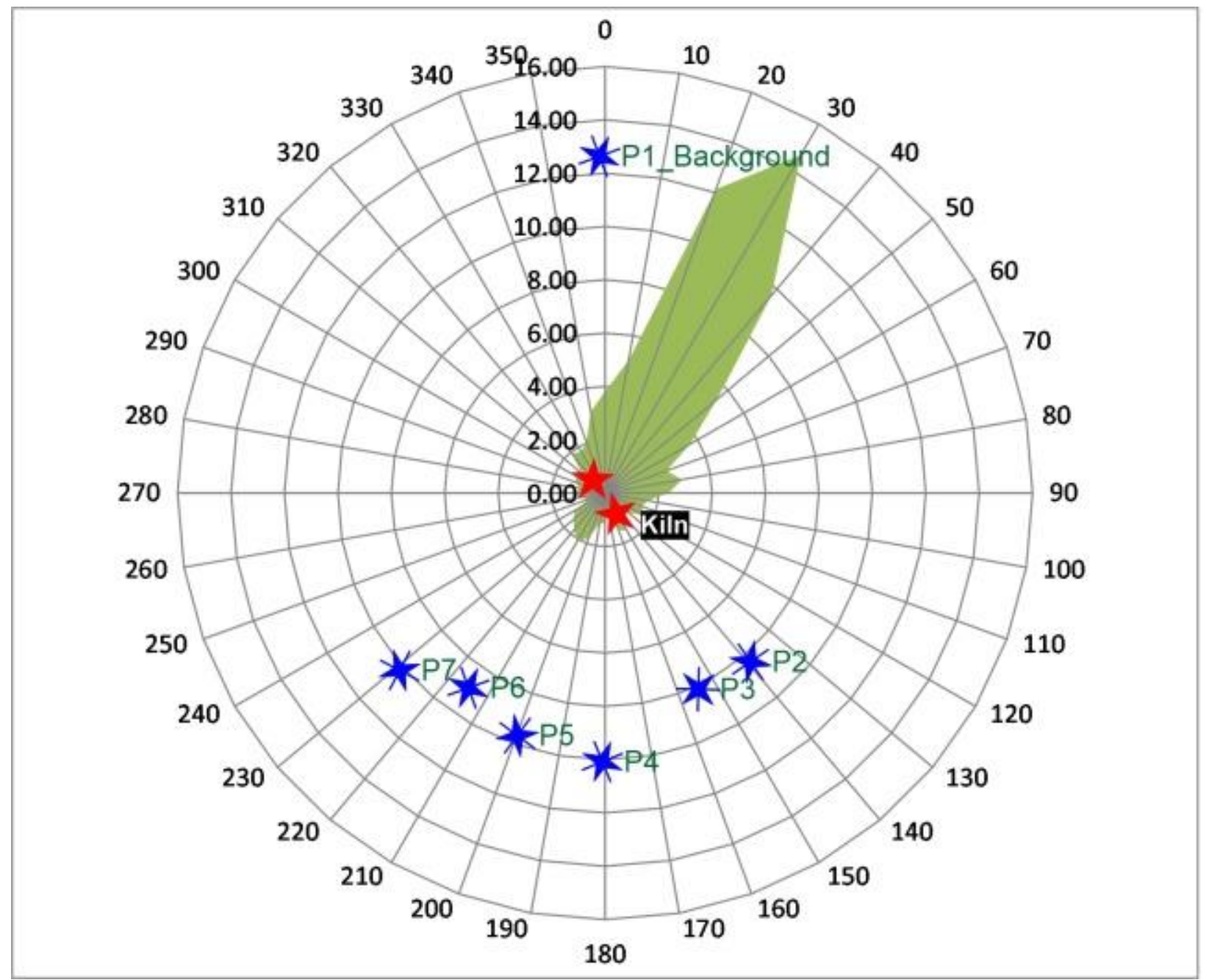

Figure 6: Wind rose at Site 3 indicating the strength of wind direction multiplier

Table 2: Measured and simulated $\mathrm{SO}_{2}\left(\mu \mathrm{g} / \mathrm{m}^{3}\right)$ concentrations at sampling points (simulated emission rate $=1 \mathrm{~g} / \mathrm{s}$ )

\begin{tabular}{ccccccccc}
\hline \multirow{2}{*}{ Location } & \multicolumn{2}{c}{ Site A } & \multicolumn{2}{c}{ Site B } & \multicolumn{2}{c}{ Site C } & \multicolumn{2}{c}{ Site D } \\
& Measured & Simulated & Measured & Simulated & Measured & Simulated & Measured & Simulated \\
\hline P1 & 29.19 & 7.41 & 73.77 & 9.12 & $1.83^{*}$ & 6.76 & 8.86 & 13.68 \\
P2 & 56.52 & 9.17 & 6.06 & 2.76 & 3.62 & 2.33 & $4.36^{*}$ & 12.06 \\
P3 & 87.81 & 51.94 & 29.04 & 4.34 & 14.02 & 8.84 & 28.01 & 15.6 \\
P4 & 40.59 & 43.21 & 9.86 & 5.55 & 24.05 & 13.23 & 6.6 & 16.05 \\
P5 & Missing & 7.93 & 34.89 & 6.23 & 16.66 & 26.33 & 18.25 & 15.46 \\
P6 & $3.38^{*}$ & 2.81 & 20.79 & 2.78 & 30.99 & 30.23 & 30.99 & 67.79 \\
P7 & 5.92 & 0.46 & $4.22^{*}$ & 0.38 & 66.91 & 16.73 & 16.2 & 31.4 \\
P8 & - & - & 21.58 & 6.80 & - & - & 8.99 & 20.66 \\
P9 & - & - & 44.83 & 14.17 & - & - & 14.36 & 72.53 \\
P10 & - & - & 42.96 & 6.31 & - & - & - & - \\
\hline
\end{tabular}

* Taken as background or ambient concentration i.e. ambient concentration without input from the kiln or discard 
Table 3: Reverse modelling methodology for Site C

\begin{tabular}{cccccccc}
\hline Location & $\begin{array}{c}\text { Measured } \\
\left(\mu \mathrm{g} / \mathrm{m}^{3}\right)\end{array}$ & $\begin{array}{c}\text { Measured } \\
\text { minus } \\
\text { background } \\
\left(\mu \mathrm{g} / \mathrm{m}^{3}\right)\end{array}$ & $\begin{array}{c}\text { Modelled } \\
(\mathrm{as} 1 \mathrm{~g} / \mathrm{s}) \\
\left(\mu \mathrm{g} / \mathrm{m}^{3}\right)\end{array}$ & $\begin{array}{c}\text { Implied } \\
\text { emission } \\
\text { rate }\end{array}$ & $\begin{array}{c}\text { Frequency } \\
\text { multiplier } \\
(\text { hours })\end{array}$ & $\begin{array}{c}\text { Emission rate } \\
(\mathrm{g} / \mathrm{s})\end{array}$ & $\begin{array}{c}\text { Emission rate } \\
(\mathrm{g} / \mathrm{s} . \mathrm{brick})\end{array}$ \\
\hline $\mathrm{A}$ & $\mathrm{B}$ & $\mathrm{C}$ & $\mathrm{D}$ & $\mathrm{E}$ & $\mathrm{F}$ & $\mathrm{G}$ & $\mathrm{H}$ \\
\hline P1 & 1.83 & 0.00 & 6.76 & 0.0000 & 0 & & \\
P2 & 3.62 & 1.79 & 2.33 & 0.7690 & 14 & & $6.0260 \times 10^{-7}$ \\
P3 & 14.02 & 12.19 & 8.84 & 1.3792 & 25 & & \\
P4 & 24.05 & 22.22 & 13.23 & 1.6792 & 47 & 1.3860 & \\
P5 & 16.66 & 14.83 & 26.33 & 0.5632 & 149 & & \\
P6 & 30.99 & 29.16 & 30.23 & 0.9647 & 119 & 67 & \\
P7 & 66.91 & 65.08 & 16.73 & 3.8897 & 67 & \\
\hline
\end{tabular}

Step-by-step description of reverse modelling technique:

- Column B gives the measured values of the ambient concentration.

- Column $C$ deducts the ambient background concentration $\left(1.83 \mu \mathrm{g} / \mathrm{m}^{3}\right)^{\star}$ from the measured values.

- Column D gives the values of the modelled concentrations at an assumed emission rate of $1 \mathrm{~g} / \mathrm{s}$.

- Column $\mathrm{E}$ is the ratio of column $\mathrm{C}$ to column $\mathrm{D}$, in order to generate the emission rate at the source from results at that measuring point.

- Column $\mathrm{F}$ gives the frequency multiplier of the wind. That is, the number of hours for which the wind was prevalent in the direction of a particular sampling point from the source. The frequency multiplier illustration is presented in Figure 6 .

- Column G multiplies each wind frequency multiplier factor (column F) by the implied emission rate (column E) and divides that by the total number of hours (frequency multiplier) to give an average.

- Column $\mathrm{H}$ provides the final emission rate per brick (3.2 million bricks for Site $\mathrm{C}$ ).

$\mathrm{SO}_{2}$ emission rates and emission factors for the 3 clamp kiln site are presented in Table 4. Mean $\mathrm{SO}_{2}$ emission factor across the 3 sites was calculated to give $2.58 \mathrm{gram} \mathrm{SO} \mathrm{S}_{2}$ per brick fired ( $\mathrm{g} / \mathrm{brick}$ ) or $0.91 \mathrm{gram}$ $\mathrm{SO}_{2}$ per kilogram of bricks fired $(\mathrm{g} / \mathrm{kg}$ ), with values ranging from 1.91 to $3.24 \mathrm{~g} / \mathrm{brick}$ or 0.67 to $1.14 \mathrm{~g} / \mathrm{kg}$. These results are comparable with similar brick firing technologies, such as tunnel kiln $-0.72 \mathrm{~g} / \mathrm{kg}$, Zigzag kiln $-0.32 \mathrm{~g} / \mathrm{kg}$, fixed chimney Bull's trench kiln $-0.66 \mathrm{~g} / \mathrm{kg}$ and vertical shaft brick kiln $-0.54 \mathrm{~g} / \mathrm{kg}$ (Maithel et al. 2012; Weyant et al. 2014).

The variation in $\mathrm{SO}_{2}$ emission rates and emission factors may be attributed to the high variability in energy input across the three sites. A direct correlation is observed between the energy input and the emission rates/factors. Site A received the highest energy input and consequently has the highest emission rates/factors, while Site $C$ received the lowest energy input, and also produced the lowest emission rates/factors. Other input and environmental variables, including the method employed in packing and firing the bricks, and the intrinsic properties of the coal and clay materials (e.g. sulfur and moisture content), may also contribute to the high variability in emission factors obtained (Akinshipe 2013).

Table 4: Clamp kiln emission rate and emissions factor

\begin{tabular}{cccccc}
\hline Site & $\begin{array}{c}\text { Quantity of bricks } \\
\text { fired }\end{array}$ & $\begin{array}{c}\text { Energy input } \\
(\mathrm{MJ} / \mathrm{kg})\end{array}$ & $\begin{array}{c}\text { Emission rate } \\
(\mathrm{g} / \mathrm{s} . \mathrm{brick})\end{array}$ & $\begin{array}{c}\text { Emission factors } \\
(\mathrm{g} / \mathrm{brick})\end{array}$ & $\begin{array}{c}\text { Emission factors } \\
(\mathrm{g} / \mathrm{kg})\end{array}$ \\
\hline $\mathrm{A}$ & 1000000 & 4.49 & $1.81 \times 10^{-6}$ & 3.24 & 1.14 \\
$\mathrm{~B}$ & 7142290 & 2.73 & $1.24 \times 10^{-6}$ & 2.60 & 0.92 \\
$\mathrm{C}$ & 3200000 & 1.41 & $4.33 \times 10^{-1}$ & 1.91 & 0.67 \\
\hline \multicolumn{7}{l}{ Average emission factors \pm standard deviation } & $2.58 \pm 0.5$ & $0.91 \pm 0.2$ \\
\hline
\end{tabular}

A comparison between emission rate obtained from a fuel mass balance and from reverse modelling technique using "bi-point", area and volume source configurations is shown in Table 5. For the two kilns that reliable results were obtained, the reverse modelling technique simulated emission factor that is $22 \%$ larger than the fuel sulfur mass balance analysis at Site $A$ and $9 \%$ less than the fuel sulfur mass balance concentration at Site B. Given the uncertainty associated with dispersion modelling, as well as the influence of external sources of $\mathrm{SO}_{2}$ which could not be accounted for, this result is considered satisfactory. Mass balance results could not be obtained at Site $\mathrm{C}$ due to discrepancies in data collection and laboratory analysis. It is also worthy to note that mass balance analysis for sites A and B indicated that over $95 \%$ of the sulfur in the coal is emitted into the atmosphere.

In addition, comparing emission factor results adopting "bi-point", area and volume source configurations for the reverse dispersion modelling technique reveals that the area and volume source simulations produced much lower results which is approximately $32 \%$ (volume source) and $45 \%$ (area source) of the mass balance result. This suggests that the elevated "bi-point" source configuration provides a better modelling 
option for clamp kiln reverse modelling technique. This option may be extended to dispersion simulations for any volume or complex source with an internal energy component capable of generating buoyant emissions.

Table 5: Comparing $\mathrm{SO}_{2}$ emission factors from fuel mass balance and from reverse modelling technique using "bi-point", area and volume source configurations

\begin{tabular}{ccccc}
\hline Site & $\begin{array}{c}\text { Fuel mass balance } \\
\text { (g/brick) }\end{array}$ & $\begin{array}{c}\text { "Bi-point" source } \\
\text { (g/brick) }\end{array}$ & $\begin{array}{c}\text { Area source } \\
\text { (g/brick) }\end{array}$ & $\begin{array}{c}\text { Volume source } \\
\text { (g/brick) }\end{array}$ \\
\hline A & 2.66 & 3.24 & 1.45 & 0.93 \\
B & 2.85 & 2.60 & 1.06 & 0.77 \\
C & - & 1.91 & 1.20 & 0.95 \\
\hline
\end{tabular}

Attempting a similar technique for the $\mathrm{NO}_{2}$ emissions proved unsatisfactory. The $\mathrm{NO}_{2}$ emission rate could not be calibrated due to the irregularity of the ambient $\mathrm{NO}_{2}$ concentrations downwind of the kiln. The sampling points that were taken as background concentration for $\mathrm{SO}_{2}$ returned relatively higher $\mathrm{NO}_{2}$ concentration, presumably due to the influence of on-site and/or off-site air emission sources.

The irregularity in $\mathrm{NO}_{2}$ reverse modelling may be associated with the complexity regarding $\mathrm{NO}_{2} / \mathrm{NOx}$ ratio released from the kiln. It has been shown by USEPA (1999), Bartok and Sarofim (1991) and Heywood (1988) that nitrogen oxide (NO), a form of the oxides of nitrogen (NOx), is formed from the combustion of fossil fuels at high temperatures; while $\mathrm{NO}_{2}$ is formed at lower temperatures in the atmosphere. Hence, quantifying the proportion of $\mathrm{NO}_{2}$ emissions from the kiln may prove difficult, since the fraction of $\mathrm{NO}_{2} / \mathrm{NOx}$ released from the kiln, as well as the oxidation rate between the release point and the samplers are unknown.

In addition, calculation of $\mathrm{NO}_{2}$ emission from the clamp kilns and from internal combustion engines in plant vehicles, using emission factors given for internal combustion engines by the NPI (2011) and suggested for the kiln by Burger and Breitenbach (2008), indicates that internal combustion engines may emit between $38 \%$ and $50 \%$ of the total $\mathrm{NO}_{2}$ emissions on a clamp kiln site. As the position of the vehicles is not fixed over the clamp firing period, this does not allow for the use of fixed point source modelling. While it may be argued that $\mathrm{SO}_{2}$ is also released from internal combustion engines, the relatively low levels of $\mathrm{SO}_{2}$ concentrations in the samplers taken to be background concentration suggests that there is significant input of $\mathrm{NO}_{2}$ concentration from on-site and/or off-site sources.

Consequently, actual $\mathrm{NO}_{2}$ background concentration could not be obtained and the reverse modelling technique could not be performed for $\mathrm{NO}_{2}$.

\subsection{Coal Discard Results}

The isopleth plot showing the maximum hourly downwind $\mathrm{SO}_{2}$ concentration for an assumed emission rate of $1 \mathrm{~g} / \mathrm{s}$ at site D (with position of the ambient measuring points indicated) is illustrated in Figure 7. Sampling point 2 returned the lowest measured and simulated $\mathrm{SO}_{2}$ concentration, and was consequently taken as background concentration. Measured and modelled $\mathrm{SO}_{2}$ results have also been presented in Table 2 for Site D.

Statistical analysis of data was performed for site $D$ using similar approach to the clamp kiln analysis. A moderate positive correlation was observed between measured and simulated data for site $D(r=0.47, n=9$, $\mathrm{p}<0.205)$. This suggests that $\mathrm{SO}_{2}$ emission contribution from external sources aside from the coal discard may be moderate or high, offering a moderate degree of confidence in the measured data. 


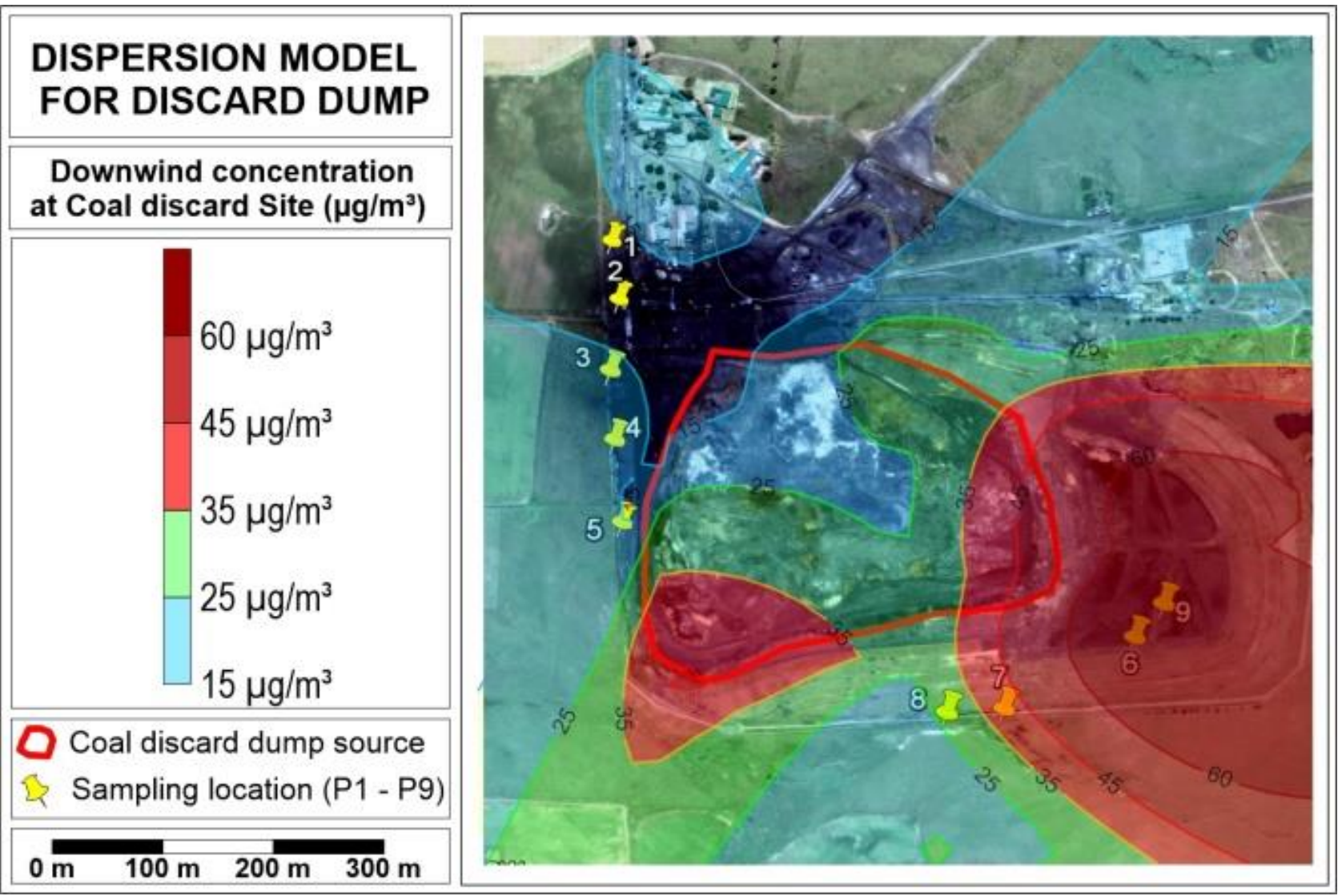

Figure 7: Modelled maximum hourly downwind concentration for $\mathrm{SO}_{2}$ in $\mu \mathrm{g} / \mathrm{m}^{3}$

A similar reverse modelling technique, as described for the clamp kilns, was utilized for the coal discard dump. Reverse modelling technique results show that 0.35 gram of $\mathrm{SO}_{2}$ is emitted from the discard every second.

According to Kalenga (2011) and Bell et al. (2001), the percentage of sulfur in South African coal discard is \pm $2 \%$. Therefore, the estimated amount of discard burning in the dump was calculated to give $8.67 \mathrm{~g} / \mathrm{s}$ or 273.4 tons/annum, based on $\mathrm{SO}_{2}$ emission rate of $0.35 \mathrm{~g} / \mathrm{s}$ and an assumed sulfur content of $2 \%$ in the coal discard dump. It should be noted that, in quantifying annual emission rate, it was assumed that the $\mathrm{SO}_{2}$ emission rate of $0.35 \mathrm{~g} / \mathrm{s}$ (calculated over a 14 days monitoring and modelling period), will be consistent over an entire year. However, emissions are likely to vary over time. Since $\mathrm{NO}_{2}$ emission quantification for clamp kilns were unsuccessful, $\mathrm{NO}_{2}$ emission quantification for the coal discard dump was not investigated.

Table 6: Estimated rate of $\mathrm{SO}_{2}$ emission and discard material burning in the coal discard dump

\begin{tabular}{ccc}
\hline Activity & $\mathrm{g} / \mathrm{s}$ & ton/annum \\
\hline $\mathrm{SO}_{2}$ emission rate & 0.35 & 10.93 \\
Discard material combusted & 8.67 & 273.4 \\
\hline
\end{tabular}

\section{Conclusions}

Reverse dispersion modelling was utilized in quantifying $\mathrm{SO}_{2}$ and $\mathrm{NO}_{2}$ emissions from clamp kilns for firing clay bricks and spontaneous combustion from a coal discard dump. The reverse dispersion modelling technique utilized ambient monitoring and dispersion simulation to calculate actual emission rates from an assumed rate of $1 \mathrm{~g} / \mathrm{s}$. Emission rate and emission factor quantification was successfully carried out for $\mathrm{SO}_{2}$, but not for $\mathrm{NO}_{2}$, due to the influence of external $\mathrm{NO}_{2}$ sources, as well as the complexity regarding $\mathrm{NO}_{2} / \mathrm{NOx}$ ratio released from the kiln.

Mean $\mathrm{SO}_{2}$ emission factor across three clamp kiln sites was calculated to give $2.58 \mathrm{gram} \mathrm{SO}_{2}$ per brick fired or 0.91 gram $\mathrm{SO}_{2}$ per kilogram of bricks fired, with values ranging from 1.91 to $3.24 \mathrm{~g} /$ brick or 0.67 to 1.14 $\mathrm{g} / \mathrm{kg}$ across the three sites. The variation in $\mathrm{SO}_{2}$ emission rates and emission factors may be attributed to the high variability in energy input across the 3 sites, since a direct correlation is observed between energy input and the emission rates/factors. 
A comparison of the emission rate from fuel mass balance and the emission rate from reverse modelling technique at two clamp kiln site was conducted. The reverse modelling technique simulated emission factor of $22 \%$ larger than the fuel sulfur mass balance analysis at one site and $9 \%$ less than the fuel sulfur mass balance concentration at the other. Given the uncertainty associated with dispersion simulation, as well as the influence of external sources of $\mathrm{SO}_{2}$ which could not be accounted for, this result is considered satisfactory.

The source configuration input to the dispersion model that was assumed to represent the kiln was changed from a conventional area or volume source to an elevated "bi-point" source situated at the level of the kiln top, with buoyancy calculated from the carbon combustion rate. The "bi-point" source emission rate was compared with the volume and area source emission rates and it was concluded that the "bi-point" source offered a more effective means of modelling clamp kiln than the area or volume source types. Hence, the elevated "bi-point" or a "multi-point" source configuration may be considered a novel approach to dispersion simulations for any volume or area source with an internal energy source capable of generating buoyant emissions.

Emission rate for spontaneous combustion from coal discard dump was calculated as $0.35 \mathrm{~g} / \mathrm{s}$. 274 tons of discard material was estimated to burn annually, assuming that the emission rate is consistent over a year.

The novelty in the reverse dispersion modelling technique is in its capability to utilize simple ambient monitoring campaign alongside dispersion simulation to quantify emissions rates and emission factors from complex configuration sources which have proven to be difficult, costly and cumbersome to quantify. It is proposed that the reverse dispersion modelling technique be adopted for quantifying emissions from combustion of materials or mixture of materials where knowledge of source parameters is limited. These complex configuration sources may include bush burning or forest fires, combustion of any stockpile of materials including municipal waste dumps and landfills etc. Although passive diffusive tubes provide an economical method for the determination of pollutant concentration, the accuracy of the technique could also be increased by utilising more sophisticated real-time monitors together with measured meteorological data over shorter time periods.

\section{Acknowledgments}

The Clay Brick Association of South Africa funded part of the study and its members were generous with their time in providing data and site amenities.

\section{References}

Adamski S (2003) Prevention of spontaneous combustion of backfilled plant waste material. Safety in Mines Research Advisory Committee. South Africa

Ahmad M, Leon J, Shah $\mathrm{H}$, et al (2011) Hydrogen fluoride damage to vegetation from peri-urban brick kilns in Asia: A growing but unrecognised problem? Environ Pollut 162:319-324. doi: 10.1016/j.envpol.2011.11.017

Akinshipe O (2013) The development of an "emission inventory tool" for brick making clamp kilns. University of Pretoria

Assadi A, Abdollah G, Fatemeh M, et al (2011) Impact of air pollution on physiological and morphological characteristics of Eucalyptus camaldulensis. J Food Agric Env 9:676-679.

Bartok W, Sarofim A (1991) Fossil Fuel Combustion: A Source Book. John Wiley \& Sons

Baum E (2010) Black Carbon from Brick Kilns. Clean Air Task Force. India

Bell F, Bullock S, Hälbich T, Lindsay P (2001) Environmental impacts associated with an abandoned mine in the Witbank Coalfield, South Africa. Int J Coal Geol 45:195-216. doi: 10.1016/S0166-5162(00)00033-1

Burger L (1986) A High Resolution Model for Multiple Source Dispersion of Air Pollutants under Complex Atmospheric Structure. University of Natal, South Africa

Burger L, Breitenbach N (2008) Air Quality Impact Assessment of Apollo Bricks Atlantis Manufacturing Facility (Brakkefontein): Proposed Dryer and Tunnel Kiln Process. Airshed Planning Professionals (Pty) Ltd. Midrand, South Africa

Cardenas B, Bouwman H, Costner P, et al (2009) Unintentional released POPs from brick production in developing countries. Technical Report, Joint Research Commission, European Commission.

Carras N, Day S, Saghafi A, Williams D (2009) Greenhouse gas emissions from low temperature oxidation and spontaneous combustion at open-cut coal mines in Australia. Int J Coal Geol 78:161-168. doi: 10.1016/j.coal.2008.12.001

CBA (2015) Clay Brick Technical Guide. Clay Brick Association. Midrand, South Africa

CBA (2002) Technical brochure on how to specify or build with clay brick. Clay Brick Association. Midrand, South Africa 
CERC (2010) Atmospheric Dispersion Modelling System (ADMS 4) User Guide. Cambridge Environmental Research Consultants. Cambridge, UK

Chatterjee R (2006) Coal fire mapping from satellite thermal IR data - a case example in Jharia Coalfield, Jharkhand, India. J Photogramm Remote Sens 60:113-128. doi: 10.1016/j.isprsjprs.2005.12.002

Clappier A, Pisoni E, Thunis P (2015) A new approach to design sourceereceptor relationships for air quality modelling. Environ Model Softw 74:66-74. doi: 10.1016/j.envsoft.2015.09.007

Cowherd C, Muleski G, Kinsey J (1988) Control of Open Fugitive Dust Sources. Office of Air Quality Planning and Standards, United States Environmental Protection Agency. California

DEA (2012) The Highveld Priority Area Air Quality Management Plan. Department of Environmental Affairs, Government Gazette. Pretoria, SA

DEA (2010) Modelling Case Study of Section 21 Emission Standards for Industrial Sources in the Highveld Priority Area. Department of Environmental Affairs. Pretoria, SA.

DEA (2013) National Environment Management: Air Quality Act-List of activities which may result in atmospheric emissions which have or may have a significant detrimental effect on the environment, including health, social conditions, economic conditions. Department . Pretoria, SA

Guttikunda S, Begum B, Wadud Z (2012) Particulate pollution from brick kiln clusters in the Greater Dhaka region, Bangladesh. Air Qual Atmos Heal 6:357-365. doi: 10.1007/s11869-012-0187-2

Heffern E (2004) Geologic history of natural coal-bed fires, Powder River basin, USA. Int J Coal Geol 59:2547. doi: 10.1016/j.coal.2003.07.002

Heywood J (1988) Internal Combustion Engine Fundamentals. McGraw-Hill, New York

Irm F (2011) Impact of brick kiln emissions on the ambient air quality and vegetation-A case study of district Budgam. University of Kashmir

Jennings AA, Kuhlman SJ (1997) An air pollution transport teaching module based on GAUSSIAN MODELS 1.1. Environ Model Softw 12:151-160. doi: 10.1016/S1364-8152(97)00005-4

Kalenga P (2011) Determination and Characterization of Sulphur in South African Coal. University of Witwatersrand

Le H, Oanh N (2010) Integrated Assessment of Brick Kiln Emission Impacts on Air Quality. Env Monit Assess 171:381-394. doi: 10.1007/s10661-009-1285-y

Lu P, Liao G, Sun J, Li P (2004) Experimental research on index gas of the coal spontaneous at lowtemperature stage. J Loss Prev Process Ind 17:243-247. doi: 10.1016/j.jp.2004.03.002

Maithel S, Lalchandani D, Malhotra G, et al (2012) Monitoring of brick kilns \& strategies for cleaner brick production in India. Shakti Sustainable Energy and Climate Works Foundation. India

Nolter A (2004) Looking back at the Centralia coal fire: a synopsis of its present status. Int J Coal Geol 59:99-106. doi: 10.1016/j.coal.2003.12.008

NPI (2011) Emission Estimation Technique Manual for Mining. Australia

Pone J, Hein K, Stracher G, et al (2007) The spontaneous combustion of coal and its by-products in the Witbank and Sasolburg coalfields of South Africa. Int J Coal Geol 72:124-140. doi: 10.1016/j.coal.2007.01.001

Potgieter J, Jansen A (2010) Generic Air Quality Impact Assessment for Clamp Clay Brick Manufacturing. EnviroNgaka CC. South Africa

Prahm L, Christensen M (1977) Validation of a multiple source gaussian air quality model. Atmos Environ 11:791-795. doi: 10.1016/0004-6981(77)90040-3

Rajasthan State Pollution Control Board (2011) Environmental guidance manual: Brick kilns. Administrative Staff College Report. India

Salcedo RL. (1991) Dispersion, An Integrated Approach to Gaussian Modeling. Environ Model Softw. doi: 10.1016/0266-9838(91)90004-A

Sheail J (2005) "Burning bings": a study of pollution management in mid-twentieth century Britain. J Hist Geogr 31:134-148. doi: 10.1016/j.jhg.2004.04.001

Sigma-Aldrich (2016) Passive (Diffusive) Sampling Overview. http://www.sigmaaldrich.com/analyticalchromatography/air-monitoring/passive-sampling.html. Accessed 12 Sep 2016

Skinder B, Pandit A, Sheikh A, Ganai B (2014) Brick kilns: Cause of Atmospheric Pollution. J Pollut Eff Cont 2:112. doi: $10.4172 / 2375-4397.1000112$

Smith A (2013) Clay Bricks and Clay Blocks: a Resource Efficiency Action Plan. In: Green Constr. Assoc. www.strategicforum.org.uk/.../Clay_Bricks_and_Clay_Blocks_Resource_Efficiency_Action_Plan.pdf. Accessed 17 Mar 2016

Stracher G (2004) Coal fires burning around the world: a global catastrophe. Int J Coal Geol 59:1-6. doi: 10.1016/j.coal.2004.01.001

Stracher G, Taylor T (2004) Coal fires burning out of control around the world: thermodynamic recipe for environmental catastrophe. Int J Coal Geol 59:7-17. doi: 10.1016/j.coal.2003.03.002

Umlauf G, Bouwman $\mathrm{H}$, Cardenas $\mathrm{B}$, et al (2011) PCDD/F, PCB and HCB in soil and ash from brick

Postprint: Akinshipe, $\mathrm{O}$ and Kornelius, G (2017) The quantification of atmospheric emissions from complex configuration sources using reverse dispersion modelling. Int. J. Environ. Sci. Technol. 14 (11), 2367 - 2378. DOI: 10.1007/s13762-017-1316-0. 
production sites in Kenya, South Africa and Mexico. Organohalogen Compd 73:1041-1045.

USEPA (1999) Nitrogen Oxides (NOx), Why and How They Are Controlled. Clean Air Technology Center (MD-12), Information Transfer and Program Integration Division, Office of Air Quality Planning, US Environmental Protection Agency. North Carolina, USA

Voit BF, Voit EO (2000) A 7th-grade science project casts doubt on the standard explanation of the Gaussian plume model for seepage through soil. Environ Model Softw 15:497-499. doi: 10.1016/S1364-8152(00)00026-8

Weyant C, Maithel S, Lalchandani D, et al (2014) Emissions from South Asian Brick Production. Environ Sci Technol 48:6477-6483. doi: 10.1021/es500186g

Whitehouse A, Mulyana A (2004) Coal fires in Indonesia. Int J Coal Geol 59:91-97. doi: 10.1016/j.coal.2003.03.002

World Bank (1997) Urban Air Quality Management Strategy in Asia (URBAIR). Kathmandu Valley Report, World Bank Group. New York, USA

Zhao Y, Zhang J, Chou C, et al (2008) Trace element emissions from spontaneous combustion of gob piles in coal mines, Shanxi, China. Int J Coal Geol 73:52-62. doi: 10.1016/j.coal.2007.07.007 